\title{
ARCTIC AND SUBARCTIC MARINE ECOLOGY: IMMEDIATE PROBLEMS*
}

\author{
M. J. Dunbar ${ }^{\dagger}$
}

7 The study of marine biology in the north has been pursued, in the past, mainly by the Scandinavian countries. In the northern waters which Scandinavian biologists do not normally visit, and especially in the North American Arctic, marine investigation is in its infancy, and has even lagged behind terrestrial ecology in the same area. As there are now signs that this condition is to be put back in balance, this is the proper time to review briefly the most interesting results of the past and to point out the most promising fields of study for the immediate future.

For the purposes of this paper the terms "arctic" and "subarctic", applied to the marine environment only, are used as defined previously (Dunbar, 1951a): the marine arctic being formed of those areas in which unmixed water of polar origin (from the upper layers of the Arctic Ocean) is found in the surface layers (200-300 metres at least). Admixture of water of terrigenous origin is ignored in this definition. The marine subarctic is defined as those marine areas where the upper water layers are of mixed polar and non-polar origin. By far the greater part of the marine subarctic lies on the Atlantic side, extending from the Scotian shelf and Hudson Strait to the Barents and Kara seas, and including almost the whole coast of west Greenland, the waters around Newfoundland and Iceland, much of the Norwegian Sea, and the waters off the west coast of Spitsbergen. The southern boundary of the marine subarctic is the limit of southward penetration of the arctic water; clearly it varies seasonally and with the state of the climatic cycle. For the large and rather ill-defined marine region south of the subarctic, the term "boreal" is used here, but with that region we are not directly concerned. It should be added that the division employed here apparently applies less to sessile animals and plants, than to the plankton and nekton, because of local variations in summer. This does not disturb the general picture, and is discussed further below.

\section{Production}

The fact that this division between the marine arctic and subarctic is not an arbitrary thing, but reflects a real and obvious difference in the biological production of the two regions, points to this difference as one of the most interesting things about the northern waters, and the study of the causes of the difference has only just begun. The fact itself is quite evident: the great

*Reprinted with some additions, from Arctic, Vol. 6 (1953) pp. 75-90.

$\dagger$ Associate Professor of Zoology, McGill University. 


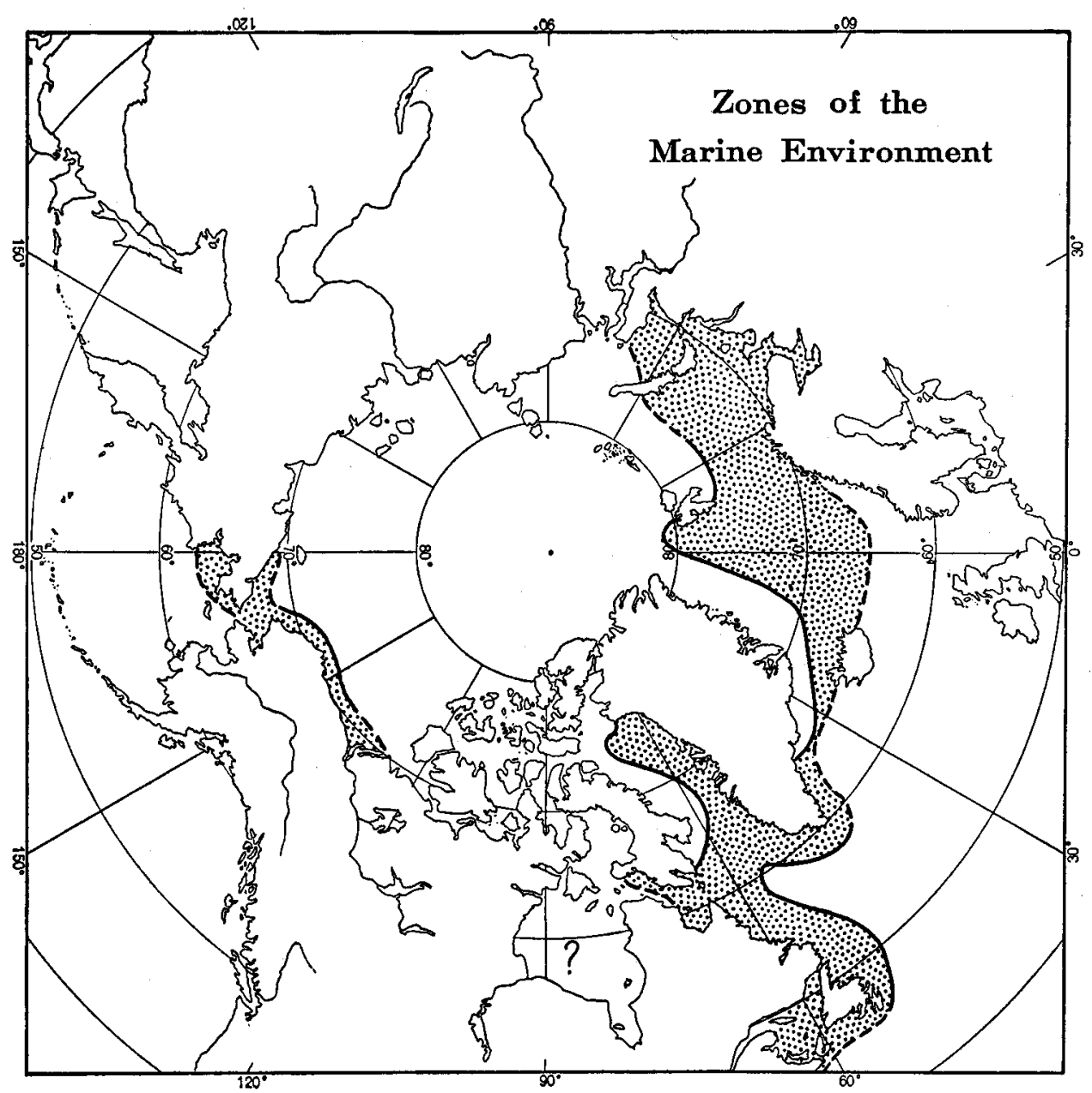

Fig. 1. ${ }^{1}$ Zones of the marine environment; the subarctic zone, as defined in the text, is stippled. The lines of delimitation are approximate, and dotted lines indicate regions still in doubt. There is some evidence that the subarctic should extend farther south in the region southeast of Iceland, northern Scotland, and western Norway, and that the coasts of Kamchatka and parts of the Seas of Okhotsk and Japan should also be included in the subarctic.

subarctic belt across the North Atlantic area is one of the richest parts of the oceans of the world, the home of fisheries of immense value, maintained by many nations of the Atlantic community. That these fish resources are dependent upon plankton production is obvious, and the same is true of other parts of the seas of great economic value, such as the subantarctic belt and the region of influence of the Peru Current off the west coast of South

1Figures 1 to 4 are reproduced from drawings prepared for the author's chapters on "Northern Waters" in the volume 'Geography of the Northlands', edited by G. H. T. Kimble and Dorothy Good, published for the American Geographical Society by John Wiley and Sons (1955). 


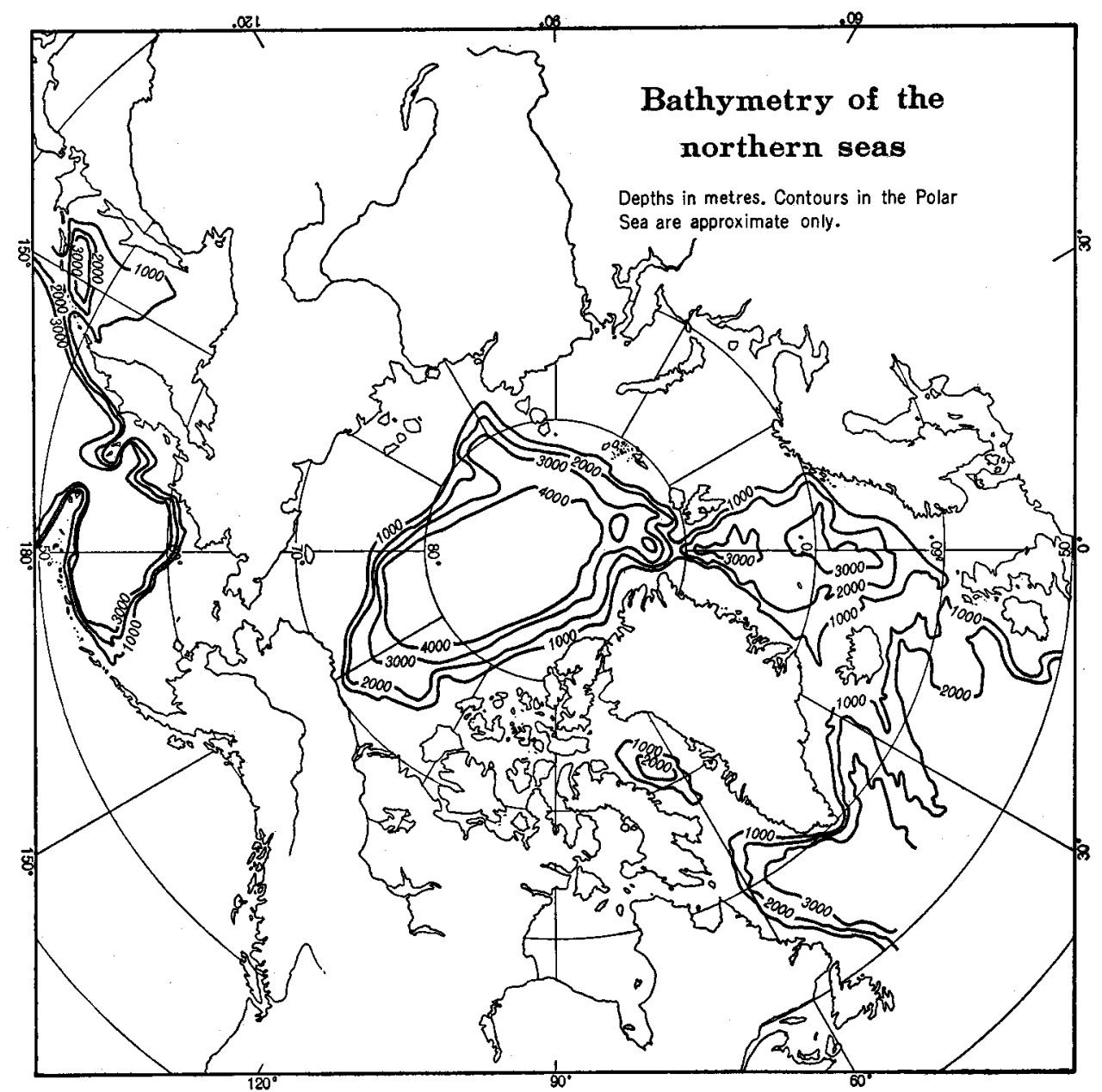

Fig. 2. Bathymetry of the northern seas. 1 The four deep enclosed basins (Arctic Ocean, Greenland and Norwegian seas, and Baffin Bay) have many faunistic points in common, although separated by submarine ridges. Notice the Wyville Thompson ridge north of Scotland and its extension to Iceland and east Greenland, also the similar ridge in Davis Strait. Both ridges rise to a water depth of about 600 metres.

America. In fact the much higher plankton production in the subarctic, when compared with the arctic, is at once apparent in the field. The quantitative measurement of this difference in production, however, is only now beginning in certain parts of the north, and is one of the next steps to be taken in the North American Arctic and Subarctic. The chemical and physical factors underlying the differences in production have also to be investigated. It may be that the high production in subarctic water is caused

1This paper was written before the preliminary publication of the Russian discovery of the Lomonosov Range across the floor of the Arctic Ocean from the Novosibirskiye Ostrova to the north coast of Ellesmere Island. 


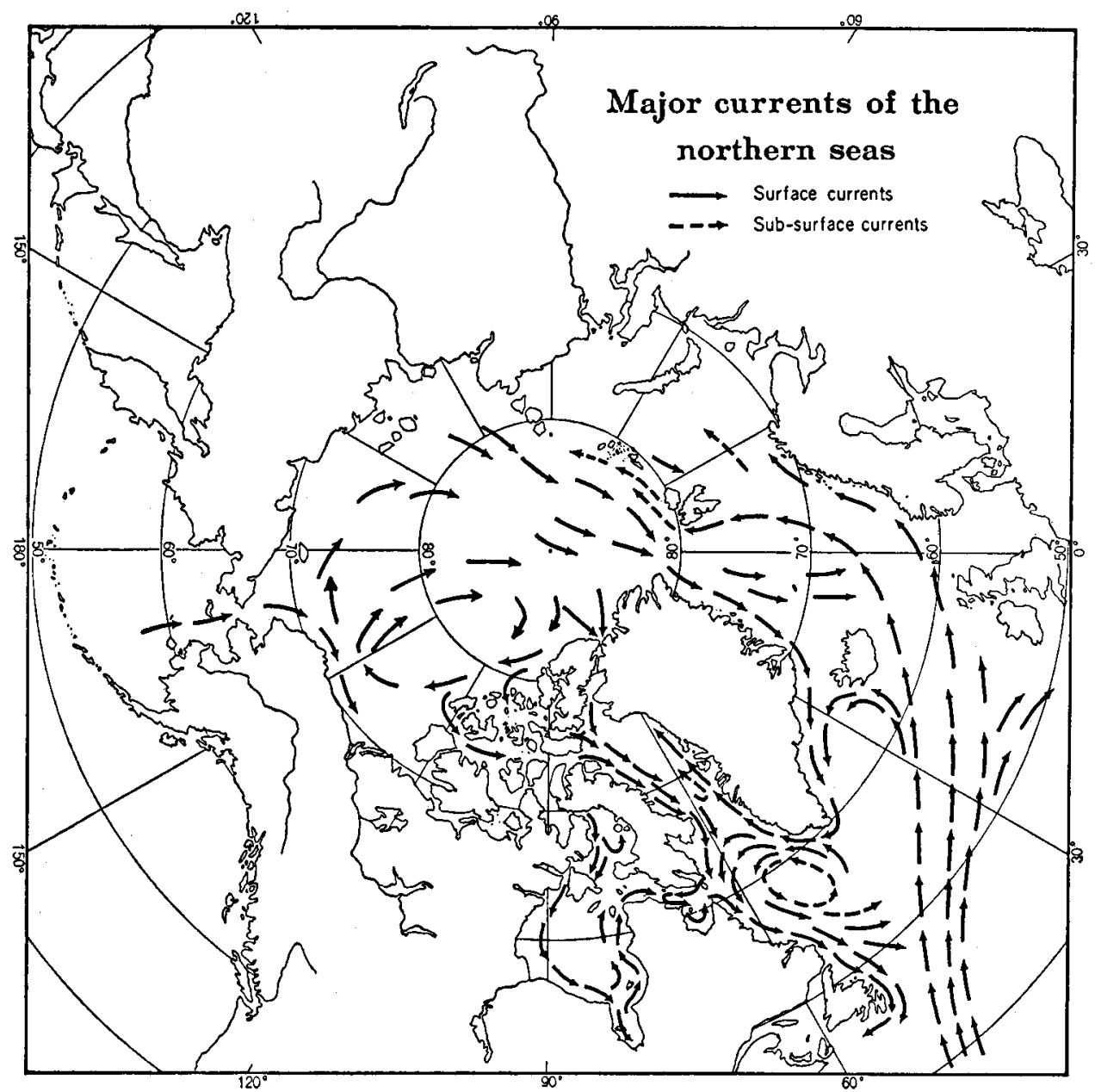

Fig. 3. Major currents of the northern seas. All details, lesser eddies etc., omitted.

simply by the lifting of the temperature inhibition in water of arctic origin (arctic water being very cold, and therefore presumably a depressant upon growth rates $^{1}$ ), which is otherwise of high production potential in such properties as gases held in solution, nutrient salts, and high viscosity; but this has still to be demonstrated. It has also been suggested that the presumed high concentration of polymerized water molecules (trihydrol or higher

1It has been demonstrated that the growth rates of the larvae of certain bottom-living forms in the arctic and subarctic are in fact no lower than in similar species in warmer water, indicating presumably a genetically established regulating mechanism, but for the mass of the zooplankton, and for the phytoplankton, there is as yet no evidence of this. In fact, the much larger generation time in colder water in the holoplanktonic animals, indicates a greatly reduced rate of growth, as has been found in marine copepods at Scoresby Sund by Digby (1953). For the pelagic larvae of benthonic species there are other pressing considerations which favour the selection of the higher growth rates, and which do not apply to the holoplanktonic forms. 
polymer) in water recently melted from ice may have a beneficial effect upon the growth and division of plant cells, as has been demonstrated experimentally. So far no method of measuring the concentration of specific water polymers has been devised.

There is another possibility in this matter of subarctic production which requires testing, namely that the high production is caused entirely by upwelling of water from lower layers, laden with plant nutrients, at all times of year. Thus the underlying cause of the high production in the Icelandic waters, and in the vicinity of the Faeroes and northern Scotland is, on this view, the presence of the submarine ridge (Wyville Thompson ridge), running from Scotland to the Faeroes, and extending from there to Iceland and east Greenland, causing upwelling of Atlantic water. The ridge between Holsteinsborg and southeast Baffin Island is supposed to play the same part in southwest Greenland. High production in the subarctic belt is thus looked upon as strictly comparable to the high production along the west African coast and the west coast of South America, although the types of water upwelling are markedly different. In the latter two regions it is cold antarctic water which comes to the surface, whereas any upwelling in the Iceland-Scotland area must be of Atlantic water. Again, it may be that the mixture of polar and non-polar water causes general instability, favouring vertical exchange of water, and that this is the important thing in determining subarctic production. It is of course clear that upwelling, wherever it occurs, will normally increase production, as it does everywhere in the usual annual succession of events. But it is still doubtful whether upwelling alone can explain the high subarctic production; it is significant that wherever arctic water meets boreal water, the production goes up. Moreover, it is by no means demonstrated that instability in subarctic waters is the rule; there is high stability, for instance, in the west Greenland coastal current in summer.

Quite apart from further hydrographic work designed to show the stability or instability of subarctic waters, and the extent of upwelling, the measurement of the phosphate and nitrate concentrations in both arctic and subarctic water should go far towards elucidating this interesting matter, the discussion of which dates as far back as Nansen (1902) and Gran (1902). The problem was attacked by Braarud (1935) in Denmark Strait and the east Greenland current, but it is not yet quite clear to what extent the supply of plant nutrients in the surface layers is exhausted during the phytoplankton bloom, and how soon it is replaced. It is quite possible that the phosphate is not exhausted in the arctic water in the spring, and that the arctic water may always have a significant surplus of phosphate and nitrate to contribute to the subarctic, even in summer. ${ }^{1}$ The Russian Papanin expedition of 1937 found that although the phytoplankton growth in the Arctic Ocean in July was poor, there was considerable flowering in August, by which time the snow cover had melted and the penetration of light became possible. The presence of considerable

\footnotetext{
${ }^{1}$ Measurements of phosphate by the Dana expeditions of recent years have shown low values, down to zero at the surface in July, in east Greenland. Measurements made by the Calanus expedition, however, in Cumberland Sound, Baffin Island, show somewhat higher values and the Godtbaab results were variable. The question is by no means settled.
} 
quantities of phytoplankton beneath the ice in summer is also recorded from Point Barrow (MacGinitie, 1949, personal communication). If the use of the plant nutrients occurs so late in the season in the Arctic Ocean, it may well follow that the outflow of nutrients in the east Greenland current and through the Canadian Archipelago in the spring is quite large.

The measurement of the amount of plankton can be done in several ways. The number of plant cells can be counted directly from samples collected in water samplers and preserved in weak formalin, a method which was used by Gran (1929) and by Braarud (1935), and which is at present being employed by Grøntved (1953, personal communication) on samples from west Greenland, with good results. The zooplankton, excluding the largest members, is measured by the use of vertical nets, or by quantitative mechanical sampler. Both these methods measure the "standing crop", or concentration of organisms at a given time, and they are reliable if enough samples are taken. Chemical methods, measuring the consumption or production of a given element of metabolism, provide an estimate of the rate of production; a recent innovation in this field is the Carbon-14 method developed by Steemann Nielsen (1952) and used on the Galathea expedition. All these methods should be applied to the North American Arctic and Subarctic.

There are particular areas where such study of the plankton production would be of special interest, such as Hudson Bay, the Arctic Ocean itself, and the Beaufort Sea. The latter, although strictly speaking a part of the Arctic Ocean, is nevertheless clearly influenced by non-arctic water from the Bering Sea. Hudson Bay is highly stratified in summer, and it has been supposed that the apparent low production of the Bay (which still has to be confirmed) is caused by the lack of proper vertical exchange of water during the winter. There are thus two points to be cleared up in Hudson Bay: the actual level of production of living matter, and the winter hydrographic regime. The latter can of course only be done by working stations through the ice, a technique which has already been tried out on several occasions: by the Danish Three Years expedition in east Greenland (1931-4), by the Papanin expedition of 1937, by P. Digby at Scoresby Sund, and by D. Nutt in the Goose Bay region in 1952. A technique of through-the-ice work is described and illustrated in Thorson's (1946) most useful paper on future work in arctic animal ecology.

The plankton production in the Arctic Ocean itself has been a matter of contention for many years, but it has never yet been measured. Nansen, after the famous Fram expedition of 1893-6, concluded that the Arctic Ocean was a barren area, because his plankton nets caught little plankton and the seal population seemed very low. Stefansson, on the other hand, having lived on seal during a prolonged trek across the polar ice during the Canadian Arctic expedition of 1913-18, obtained a quite different impression, and reported, moreover, the abundance of so-called "shrimps" (possibly a pelagic amphipod) in the surface water between the ice floes. The collections of the Russian Papanin expedition of 1937 apparently confirmed Stefansson's conclusions rather than Nansen's, although the final plankton results do not seem to have appeared yet. Clearly this situation calls for decisive study, and the only way 
to do it is to maintain regular quantitative plankton collections all year round at one station, chosen for ease of access and depth of water. Probably the coast of northern Ellesmere Island, or of Greenland, offers the best conditions. The penetration of light at all seasons of the year, and the oxygen and phosphate concentrations, should of course be measured at the same time.

Before leaving the subject of production, mention should be made (1) of the necessity for study of winter as well as summer conditions in all phases, both in those areas normally frozen over, and in the ice-free subarctic regions of southwest Greenland, and (2) of the need for bacterial studies in northern seas, in order to establish the rate of bacterial mineralization of organic detritus.

\section{Plankton biology in general}

There are other facets of plankton biology in cold waters which offer valuable returns for research, but which can be mentioned here only in summarized form:

(1) Vertical diurnal migration of the plankton, a normal phenomenon all over the world and largely dependent upon changes in illumination, was observed in Svalbard waters, latitude $80^{\circ}$, in 1893 by Walther, even in the height of summer when the sun was well above the horizon at midnight. Walther was surprised to find this phenomenon so far north in summer, but Russell (1927) has since pointed out that the illumination which is able to penetrate the surface at that latitude in June, at midnight, is very much less, midnight sun or no midnight sun, than the penetration at noon. Later, however, Bogorov (1946) published his observations in the Barents Sea, in which he found no evidence of vertical migration during the height of summer. Clearly this problem needs further research.

(2) Cold-water plankton is remarkable for the large size attained by the individuals, when compared with the same or closely related species in temperate or warmer waters. It has been assumed that the effect of the low temperature on the development of the gonads is one important factor: "Delayed sexual maturity, which favors growth in size, appears to be directly dependent on retardation of growth at lower temperatures, and this is a common characteristic of northern marine creatures" (Hesse, Allee, and Schmidt, 1937, p. 159). It is not yet clear, however, why the gonadial growth does not maintain the same rate, relative to somatic growth, as in warmer water. It may be that so much energy is required to offset the very low environmental temperatures that the gonads are penalized in favour of the general metabolism. Large size is an advantage at low environmental temperatures, for poikilotherms as for homoiotherms, but in poikilotherms it requires a longer life to achieve it (relative to the size of the species), because growth rates are controlled by the environment (see footnote p. 216); the adjustment of the gonadial and somatic growth rates may therefore be established in the hereditary mechanism of the species, and may not be simply and directly controlled by the external temperature. At all events, in order to throw light on this perennially puzzling matter, an investigation of the metabolism 
of arctic plankton animals is needed. The measurement of the oxygen requirements of arctic plankton can be done in an adequately equipped ship's laboratory, but more simply in a shore station. The results would dovetail usefully with the work of Thorson (1936), who studied the oxygen metabolism of shallow-water benthonic forms, mostly molluscs, in northeast Greenland, and found that the metabolic rate was approximately the same as in closely related temperate (Danish) species and in tropical species, each group being measured at their normal environmental temperatures. Measured at the same temperature, the arctic forms showed a considerably higher metabolic rate. Such remarkable metabolic regulation was not found in a variety of arctic aquatic forms by Scholander et al. (1953). The whole matter of body size and metabolic rate has recently been reviewed, with considerable new experimental work, by Zeuthen (1947), and a theoretical development of the question has been published by Hemmingsen (1950).

(3) Thorson (1946, p. 25) mentions the food of zooplankton in the north as requiring research. To quote one point from his paper: "Ussing [1938] is of opinion that in winter most copepods [in east Greenland] are able to live on the food obtained in summer (stored as oil drops). Place, therefore, such winter-copepods in sterile sea-water to have this problem cleared up." This work, together with the metabolic study already mentioned and other research discussed below, needs wintering parties with laboratories equipped with constant temperature aquaria, filtering devices, and so on. Laboratories aboard research vessels, even small vessels, should also be similarly equipped if possible.

(4) Breeding cycles of planktonic animals, the nature of which is fundamental to the production of the standing crop each year, require a great deal of study, and for best results also call for winter as well as summer work. The fact that interesting complications arise in the breeding cycles of certain zooplankters in the north has already been demonstrated by Dunbar (1941). Generation time in certain copepods has been studied by Ussing (1938), and the bimodal size-distributions in copepods found in northern waters by Ussing and by Jespersen (1934) are also involved in this matter of breeding cycles. The suggestion of Ussing that the surface water of fjords, which is warmed in summer time and which has been called "fjord water" by the Danish workers, is important and perhaps essential to the survival of arctic copepods, requires testing.

\section{Benthonic and littoral fauna}

Many benthonic and littoral animals are sessile, and all of them, except the fishes, are limited in powers of locomotion and dispersal. Most of them, moreover, are restricted in their distribution with respect to depth. These circumstances make it less simple to follow the arctic-subarctic pattern of distribution in the benthos and littoral than in the plankton and nekton. Largescale changes in the position and extent of the subarctic marine belt will of course result in extinctions of sessile populations and their replacement by others, but at any time during this climatic cycle there will always be seasonal differences in temperature in the upper 30-50 metres of water, which will greatly affect the distribution and living conditions of these forms. This has 
been pointed out and developed in a very interesting manner by Lemche (1941), for the opisthobranch gastropods of east Greenland. Forms of more southerly affinities are found in northeast Greenland in the upper waters only, where reproduction can take place at less rigorous temperatures in the summer. Below this zone there is a population of arctic forms which live at the lower temperatures all year round. Consequently, if the distribution of the two groups are placed on the same map without taking depth into account, they are found to coincide almost exactly in east Greenland. This of course is quite misleading, and emphasizes the fact that for the division of the benthonic fauna into arctic and subarctic regions it is essential to allow for this differentiation within the upper water layers. (The criterion employed, described above, deals with the upper 200-300 metres of water, which is the approximate depth of the arctic water layer in the Arctic Ocean; below this the depth factor applies also, naturally, to the plankton). So far, no work of this sort has been done on the North American Arctic shallow-water benthos.

The distinction between the two groups just mentioned lies in their reproductive physiology, and there is no doubt that the most promising lines of research in this ecological division lie in the elucidation of the reproductive requirements and limitations. Gunnar Thorson, of the University of Copenhagen, has made notable advances in this field, and since he has already reviewed the whole subject on a global scale (Thorson, 1950, 1951), and also established the study in arctic waters (Thorson, 1936) and indicated the points which require research in the immediate future (Thorson, 1946), it is not proposed to deal with this subject here. It must be enough to point out that a valuable contribution to the whole pattern of benthonic reproductive habits, which are of great interest, would be made by applying Thorson's methods to the North American fauna, particularly as regards the presence or absence (and length) of the larval life. There is also much work to be done on the density of the benthonic fauna, by the use of bottom samplers, along the lines of Vibe's (1939) work in the Thule and Upernavik districts. It might be added here that the questions raised by the now classical work of Orton (1920), concerning the factors determining the onset of maturity in cold water, and the time of breeding, have not yet been settled.

The term "littoral" is used here as coextensive with "intertidal", and thus not in the sense advocated by Hesse, Allee, and Schmidt (1937). The littoral fauna has special conditions to face, in which the atmospheric climate must play an important part. It was upon the marine climate, however, not the atmospheric climate, that the study of Madsen $(1936,1940)$ put the emphasis as possibly determining the distribution of northern littoral faunas. His work suggested that the littoral fauna in large part disappeared north of a point which was determined by the nature of the water, possibly by the presence or absence of Atlantic water on the coast. This point would thus coincide with the boundary between the arctic and subarctic regions as defined in this paper, and hence the nature of the littoral fauna might serve as an added indicator of hydrographic conditions. Before this possibility can be developed, a great deal of littoral collecting is necessary, especially in the North American Subarctic. 
Apart from such zoogeographical considerations, the littoral fauna of the northern seas calls for investigation of breeding seasons and breeding cycles at different levels on the beach, and of the conditions of survival during the winter, on all of which points our knowledge is extremely poor. The biology of such abundant forms as the amphipod crustacean Gammarus (several species), the barnacle Balanus balanoides, and the snail Littorina saxatilis, for instance, has scarcely been studied at all on arctic and subarctic shores; and almost nothing is known of the northern littoral microfauna.

\section{Nekton (fishes and marine mammals)}

It is in the study of the macrofaunal elements of the northern seas that we come into immediate contact with the economy of the Eskimo, and it is here that investigations intended to develop new resources, or to conserve the old, become of immediate value. They are not on that account necessarily the most important in the long run, but they appeal to the general public, and hence reach more easily for the public purse-strings than the more obscure scientific projects can hope to do.

In true arctic waters, that is, inside the arctic zone as here defined, fishes are not abundant, and the nektonic constituent in the biomass is dominated by the mammals; in the subarctic waters, fishes make up a very important part of the total fauna, and the mammals are not dominant. This interesting fact, which has as a corollary the direct dependence of the mammals, in the arctic zone, upon the macroplankton (invertebrate) instead of on the fish, has never been explained, nor has there been any attempt to throw light upon it experimentally. Speculation upon it leads to a consideration of the glacial history of the northern waters, and of the time-scale in the evolution of fishes, and although the problem of the glacial history can be attacked in various ways through the study of northern marine ecology today, it is not the purpose of this paper to develop this line of thought. It has been touched upon in another paper (Dunbar, 1951b).

The problem can also be attacked, more directly, by the study of the metabolism of arctic fishes at the temperatures at which they live, and of the general relation which their reproduction and development bear to temperature. It should be emphasized that the poverty of the fish fauna, in terms of numbers of fish species, is not itself surprising-it is part of the general picture of fewer species of most groups in arctic water. ${ }^{1}$ What has to be explained is why no

1A recent study (Thorson, 1951) has thrown a new light on the matter of species numbers in the marine environment of the arctic, temperate, and tropical regions. For the intertidal and shallow-water invertebrates, it is the "epifaunal" species which increase greatly in numbers toward the tropics, the "epifauna" including all dwellers upon the surfaces of various substrates, such as rock, stones, coral reefs, and seaweed, whereas the numbers of species in the "infauna", mainly burrowing forms in the large uniform environment of sandy and muddy bottoms, are approximately the same in comparable environments in all three major zones, tropics to arctic. In the light of this, the poverty of fish species (and also of holoplanktonic species) in the arctic water appears to be a breach of the rule, for ecologically the fishes, especially the pelagic fishes, must be compared with the benthonic and littoral "infauna", for which the environment is constant over large areas, and not broken up into a multitude of small habitats as in the epifaunal environments. 


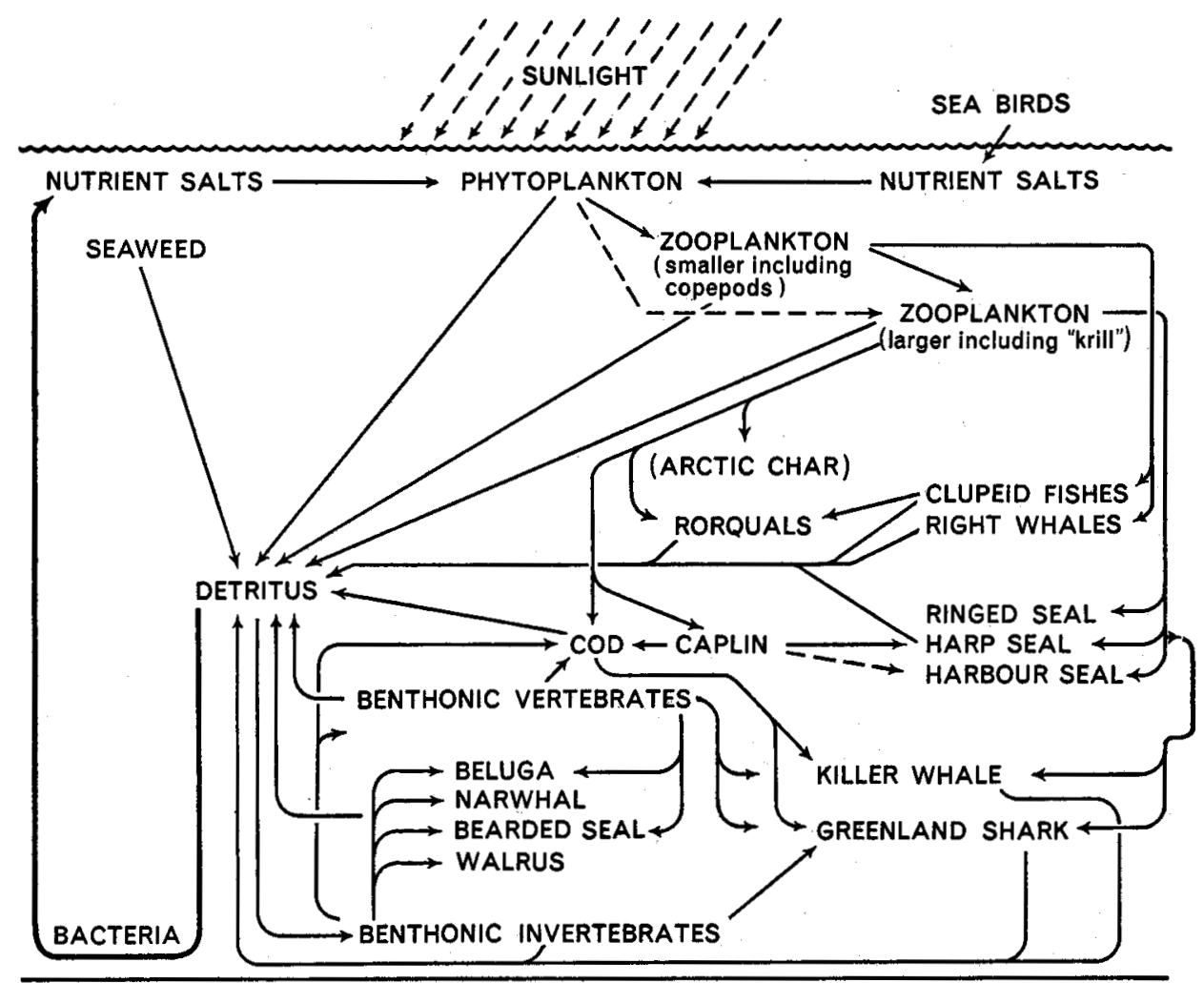

Fig. 4. The biological cycle in the arctic and subarctic marine zones, somewhat simplified. The prey-predator system illustrated in the right-hand three-quarters of the figure ends finally in the production of organic detritus, which is decomposed by bacterial action mainly on the sea-floor in moderate depths. The resulting supply of inorganic plant nutrients (nitrates, phosphates) is returned to the surface by vertical water exchange in the autumn and winter, and is thus available for the regeneration of the phytoplankton population in the springtime conditions of increasing sunlight.

single species has been able to achieve a dominant or even an important position in the total fauna, in contrast to other poikilotherms, all of them invertebrates, many of which are extremely abundant in arctic water, such as certain amphipods, copepods, and molluscs.

The poverty of the fish fauna in arctic water is particularly remarkable in the pelagial, as opposed to the littoral and benthal, regions. The polar cod, Boreogadus saida, although frequently referred to as a pelagic form because it is often seen among ice floes, is in fact much more commonly found close to the bottom in fairly shallow water; and the arctic char, Salvelinus alpinus, although in part a planktonic feeder during its short annual stay in salt water, cannot be considered a true pelagic species on that account. The shallow water benthos includes a few families of fishes which are widespread although nowhere very abundant. The young of these benthal forms, Cottids, Liparids, Agonids, Gadids, etc., are often taken in plankton nets, especially at night, and 
it is probable that much more could be learned about their abundance and their habits by the use of large (two-metre) stramin nets, and other types of small-mesh mid-water trawls. Pelagic young fish escape, for the most part, from the ordinary plankton nets. The same is true of the largest pelagic crustacea, such as the Hyperiid amphipods and the Euphausids which, like the young fish, lie on the border-line between the plankton and the nekton, and which can be collected adequately only with appropriate mid-water trawls.

The subarctic fisheries must be left out of the present paper; they are an extremely large subject in themselves. Moreover, they are being studied and developed constantly, in such areas as west Greenland, Spitsbergen, and the Norwegian, Barents, and Kara seas. There is room for considerable biological work on the economic fishes of the Labrador coast, however, and the possibilities of the Beaufort Sea have yet to be investigated fully. At the northern edge of the subarctic water, and also beyond it, there is a need for experimental fishing for such forms as the arctic halibut, Reinbardtius bippoglossoides, and the Greenland shark, Somniosus microcepbalus, in Baffin Island waters and northward. The breeding habits of the Greenland shark are still unknown. In the Burwell area of Ungava Bay the Calanus expeditions recorded the young of the arctic halibut, but the adults have not yet been taken.

In terms of man's immediate interests, there is an urgency about the scientific study of the arctic and subarctic marine mammals which does not apply to any other marine problem discussed here. The northern sea mammals have been hunted by Eskimo and by Europeans for centuries; the European killing has been for a shorter time, but has been very much more destructive. The Eskimo, by themselves and uninfluenced by Europeans, had struck a natural balance between themselves and their sea mammal resources. They were themselves part of an established ecological system. The commercial whalers and sealers, on the other hand, came from another system upon which they were dependent, and their activities among the northern sea mammals may rightly be termed an invasion. As might be expected, the species which they prized most, the Greenland whale or bowhead, was soon brought to the verge of extinction, and the introduction of the rifle to the Eskimo, by both whalers and traders, is now doing considerable damage to the seal populations. Whatever recriminations may be made about these two facts (the one is history, the other is now much more than a simple zoological problem), they have left problems which the zoologist can certainly tackle.

It is probably true that all marine mammal species in the north, at one or more points of their range, are now seriously reduced in numbers. There may be exceptions to this, for instance the white whale and the narwhal, which possibly are holding their own, but in general the marine mammal populations have been declining, and in a belated awareness of this, we are faced with the fact of our almost complete ignorance of the most elementary matters of their life histories. The cases of the Greenland whale and the walrus are particularly clear. Since the almost complete extinction of the bowhead before the First World War, it has been given protection, and there are signs now that the population has been very slowly increasing; for the present there is little to 
do about it except to leave it in peace, and to keep records of its recovery. But the walrus is another matter; there is clear evidence that the walrus was once much more widespread than it is at present, and it is improbable that this retreat has been caused entirely by changes in climate during the last four hundred years, although that may have had something to do with it. The walrus has been the object of commercial hunting for several centuries, and it is still occasionally killed in numbers by sealing vessels. It is also hunted by Eskimo armed with rifles, some at least of whom seem to have forgotten their fathers' hunting wisdom, so that there is much waste, especially in summer, which would not have occurred in earlier times, and without the rifle. The same is true of other Pinnipedia in the north. The sinking during the summer hunting, caused by shooting the animals from a distance, very often without adequate means of retrieving them, accounts for the wastage of a ridiculously large proportion of the seal and walrus. It would be a mistake to think that this matter does not come into the business of the marine biologist. The Eskimo is part of the marine system, just as the whaler is, and his activities are most important zoologically. In this connection, the designing and introduction of a good, inexpensive shoulder harpoon gun would be helpful.

We have to make a study of the life histories of the marine animals, beginning from almost nothing, in order to discover where we may apply conservation measures. A little has been published on the walrus, from Alaska (Collins, 1940) and from northwest Greenland (Vibe, 1950), but for the rest we have only scattered observations published in odd corners of expedition reports, popular books, or filed in manuscript in Government offices. There is an excellent account of the harp seal (Phoca groenlandica) of the White Sea area by Sivertsen (1941), and Fisher (1952) is conducting a thorough study of the harp seal on its Gulf of St. Lawrence breeding ground, sponsored by the Fisheries Research Board of Canada. The harp seal, like the hooded seal (Cystophora cristata), is a migrant species, spending the summer in the north. Those which breed in the Newfoundland and St. Lawrence area move to west Greenland and Baffin Bay in the spring, and they are fairly common in Ungava Bay and along the eastern and northern coasts of Baffin Island. It is in this northern part of the harp seal range that we need information on abundance, food habits, and migration. It is possible that some of the adolescent seal remain in the north during the winter; if so, it is important that we have some estimate of the numbers involved, in order that population studies done farther south, in the breeding areas, may take this into account.

For those sea mammals that breed in the north-walrus, ringed seal (Pboca bispida), bearded seal (Erignatbus barbatus), and some of the harbour seal population (Phoca vitulina), also the beluga or white whale and the narwhal, a program of research should include the following: (1) A census done by counting breeding colonies, summer schools, hunting kills, and by running counts from ships in transit, all of which must be kept up through the years. (2) The collection of reproductive tracts, stomach contents, and parasites, in sufficient numbers to give good material for laboratory study. (3) The collection of teeth and possibly certain bones (bacula, for instance) for ageing 
purposes, so that the age composition of the population may be determined; and the discovery of good methods of ageing in general (the use of teeth is quite new for seal and walrus, and there may be other means). (4) The study of migrations, especially winter distribution. It is not known, for instance, whether the walrus of Hudson Bay remain within the Bay during the winter or not, nor is it known which group of walrus visits Akpatok Island in early July each year. Something of the winter distribution could be discovered by air surveys, but the only final way of establishing migration habits is by marking the animals at the breeding grounds. This presents quite a problem, especially in species as large and formidable as the walrus, or as elusive as the beluga, and one of the most important problems to be solved is just how to mark them. ${ }^{1}$

\section{Systematic and zoogeographic studies}

The fauna of the North American Arctic and Subarctic waters and coasts (except those of Greenland) is still poorly known. The large gaps in the distribution maps are being filled in, but even when the work of the Calanus and Blue Dolpbin expeditions, and of the Point Barrow Laboratory, is published, there will still be a great deal of faunistic work to do, particularly in the Central Arctic section, and in the Beaufort Sea. The present signs are that when these groups are filled in, the results will be very interesting. Ekman (1953, p. 159) has collected evidence to show that "a considerable part of the North Atlantic boreal fauna and the Polar Sea arctic fauna is derived from the North Pacific", and although the evidence is of the equivocal sort that zoogeography is often forced to use for lack of anything better, it is also the sort that is accepted by most zoogeographers. The shelf fauna of the North Pacific contains many more species and genera than are to be found on the North Atlantic shelf, and it is only in the Pacific region that endemic families are found. Given certain premises (which are not quite argument-proof), this is evidence for the dispersal of the fauna from the Pacific to the Atlantic. However that may be, there is good indication that there has been a dispersal from the North Pacific or Bering Sea area eastward to the Canadian Eastern Arctic, and also westward to the waters of the Siberian shelf, which has hitherto left the coasts of Greenland and of northwest Europe almost untouched. This is at present represented by the land-locked seal of Seal Lakes in the Ungava Peninsula, by certain of the fishes in Hudson Bay and Ungava Bay, and by several amphipod species; and the full study of the Eastern Arctic fauna will no doubt bring many more such examples to light. Such distributions are doubtless a legacy from early postglacial times, and the whole study of arctic zoogeography has an important bearing on the glacial and postglacial history of the North American Arctic.

Within the arctic zone, the phenomenon of circumpolarity appears to be fairly common, although the addition of the North American sector to the

1Since this was written, walrus tags have been designed by both the Canadian Wildlife Service and the Fisheries Research Board of Canada, and have been used in northern Hudson Bay in the summer of 1954. 
picture may well change our ideas in this as in other aspects of northern marine distribution. It may well be that there are variations within circumpolar species, which will be significant of isolation within the circumpolar area, especially in the littoral and benthonic species; and even for holoplanktonic forms there is the possibility of isolation by current systems. In the marine subarctic, the true monotypic circumpolar species is the exception rather than the rule, and the investigation of the extent and quality of variation within subarctic genera is a matter of great interest to the student of evolution, and will be much extended by the filling in of the North American gap in our knowledge.

As for the fauna of the deep basins, there can be little doubt that even in the regions where most exploration has been made, as in the Greenland and Norwegian seas, there is still much to be added. In Baffin Bay our present knowledge is based almost entirely on the results of one short expedition, the Godthaab expedition of 1928. At the present stage of the study there appears to be a large number of species common to all the arctic basins (Arctic Ocean, Norwegian and Greenland seas, and Baffin Bay), a fact which may have interesting implications concerning the recent history of those depths. Before any firm conclusions can be drawn, however, there is much deep-water dredging and bottom sampling to be done.

There are many groups, which cannot be mentioned in detail here, whose systematics are in a somewhat chaotic state. For some of these, such as the Gadid and Liparid fishes, we need embryological studies in order to untangle the pattern of relationship, and for others, such as several amphipod families, we need large collections from the whole circumpolar field.

Finally, since zoogeography is a study of a dynamic, not a static, phenomenon, and since changes in the distribution of marine animals can be of decisive economic importance, it is necessary to keep routine observations going every year, or at regular intervals, not only upon the fauna itself, but upon the hydrographic conditions which, more than anything else, determine the composition of the fauna. Changes in the marine climate have not been treated in this paper, partly because of lack of space, partly because their existence and their overwhelming importance are now well established, and the continued study of them may be taken for granted.

The author wishes to acknowledge his indebtedness to Dr. Gunnar Thorson of the University of Copenhagen for reading the manuscript of this paper, and for valuable suggestions.

\section{References}

Bogorov, B. G. 1946. "Peculiarities of diurnal vertical migrations of zooplankton in polar seas". J. Marine Res. Vol. 6, No. 1, pp. 25-32.

Braarud, T. 1935. 'The phytoplankton and its conditions of growth'. Hvalrådets Skrifter, No. 10, $173 \mathrm{pp}$.

Collins, G. 1940. "Habits of the Pacific walrus (Odobenus divergens)". J. Mammal. Vol. 21, pp. 138-44. 
Digby, P. 1953. (Summary of paper read at the Challenger Society). Ann. Rept. Challenger Soc. Vol. 3, p. 19.

Dunbar, M. J. 1941. "The breeding cycle in Sagitta elegans arctica Aurivillius". Can. J. Res. Sect. D, Vol. 19, No. 9, pp. 258-66.

1951a. 'Eastern Arctic waters'. Fish. Res. Bd. Can. Bull. No. 88, 131 pp. Vol. 45, Ser. III, Sect. V, pp. 61-7.

1951b. "Resources of arctic and subarctic seas". Trans. Roy. Soc. Can.

Ekman, S. 1953. 'Zoogeography of the sea'. London: Sidgwick and Jackson, $417 \mathrm{pp}$.

Fisher, H. D. 1952. "Harp seals of the northwest Atlantic". Fish. Res. Bd. Can. Atl. Biol. Sta. Circular, Gen. Ser. No. 20, 4 pp.

Gran, H. H. 1902. 'Das Plankton des norwegischen Nordmeeres'. Rept. on Norw. Fishery-and Marine-Investigations, Vol. 2, No. 5, $222 \mathrm{pp}$.

1929. 'Quantitative plankton investigations carried out during the expedition with the "Michael Sars", July-Sept. 1924'. Cons. Perm. Rapp. et Proc.-Verb. Vol. $56,50 \mathrm{pp}$.

Hemmingsen, A. M. 1950. "The relation of standard (basal) energy metabolism to total fresh weight of living organisms". Rept. Steno Memorial Hospital and the Nordisk Insulinlaboratorium, Vol. 4, pp. 1-58.

Hesse, R., W. C. Allee, and K. P. Schmidt. 1937. 'Ecological animal geography'. New York: John Wiley $597 \mathrm{pp}$.

Jespersen, P. 1934. 'Copepoda, the Godthaab expedition 1928'. Medd. om Gronl. Vol. 79 , No. 10,166 pp.

Lemche, H. 1941. 'The zoology of east Greenland. Gastropoda Opisthobranchiata'. Medd. om Gronl. Vol. 121, No. 7, 50 pp.

Madsen, H. 1936. "Investigations on the shore fauna of east Greenland with a survey of the shores of other arctic regions'. Medd. om Grønl. Vol. 100, No. 8, 79 pp.

1940. 'A study of the littoral fauna of northwest Greenland'. Medd. om Grønl. Vol. 124, No. 3, 24 pp.

Nansen, F. 1902. 'The oceanography of the North Polar Basin'. Norw. North Polar exp. 1893-1896, Sci. Res. Vol. 3, Pt. 9, 427 pp.

Orton, J. H. 1920. "Sea temperature, breeding and distribution in marine animals". J. Mar. Biol. Ass. U.K. New Ser. Vol. 12, pp. 339-66.

Russell, F. S. 1927. 'The vertical distribution of plankton in the sea'. Biol. Rev. Vol. 2, pp. $213-62$.

Scholander, P. F., W. Flagg, V. Walters and L. Irving. 1953. "Climatic adaptation in arctic and tropical poikilotherms". Physiol. Zool. Vol. 26, No. 1, pp. 67-92.

Sivertsen, E. 1941. 'On the biology of the harp seal Phoca groenlandica Erxl'. Hvalraidets Skrifter, No. 26, 166 pp.

Steemann Nielsen, E. 1952. "The use of radio-active carbon (C-14) for measuring organic production in the sea". $J . d u$ Conseil, Vol. 18, No. 2, pp. 117-40.

Thorson, G. 1936. 'The larval development, growth, and metabolism of arctic marine bottom invertebrates compared with those of other seas'. Medd. om Grdnl. Vol. 100, No. 6, 155 pp.

1946. 'Technique and future work in arctic animal ecology'. Medd. om Grønl. Vol. 144, No. 4, 40 pp.

1950. "Reproductive and larval ecology of marine bottom invertebrates". Biol. Rev. Vol. 25 , pp. $1-45$.

1951. "Zur jetzigen Lage der marinen Bodentier-Okologie". Verbandl. $d$. Deutscben Zool. Gesellsch. in Wilbelmsbaven, pp. 276-327.

Ussing, H. H. 1938. "The biology of some important plankton animals in the fjords of east Greenland'. Medd. om Gronl. Vol. 100, No. 7, 108 pp.

Vibe, C. 1939. 'Preliminary investigations on shallow water animal communities in the Upernavik- and Thule-districts (northwest Greenland)'. Medd. om Grønl. Vol. 124, No. 2, 42 pp.

1950. 'The marine mammals'. Medd. om Gronl. Vol. 150, No. 6, 115 pp.

Zeuthen, E. 1947. 'Body size and metabolic rate in the animal kingdom with special regard to the marine micro-fauna'. Comptes Rendus $d$. Trav. du Laboratoire Carlsberg, Sér. Chim. Vol. 26, No. 3, 161 pp. 